\title{
Zika virus can be venereally transmitted between Aedes aegypti mosquitoes
}

\author{
Stéphanie Silva Campos ${ }^{1}$, Rosilainy Surubi Fernandes ${ }^{1}$, Alexandre Araujo Cunha dos Santos ${ }^{2}$, \\ Rafaella Moraes de Miranda', Erich Loza Telleria ${ }^{3}$, Anielly Ferreira-de-Brito', Marcia Gonçalves de Castro', \\ Anna-Bella Failloux ${ }^{4}$, Myrna C. Bonaldo ${ }^{2}$ and Ricardo Lourenço-de-Oliveira ${ }^{*}$ (D)
}

\begin{abstract}
Background: Alternative transmission routes have been described for Zika virus (ZIKV). Here, we assessed for the first time the venereal transmission of ZIKV between Aedes aegypti under laboratory conditions.

Results: Orally-infected mosquito females were able to transmit the virus to males venereally, and males inoculated intrathoracically were capable of infecting females during mating. The genome of venereally-transmitted virus recovered from males was identical to that of ZIKV ingested by mated females.

Conclusion: We conclude that venereal transmission between Aedes mosquitoes might contribute to Zika virus maintenance in nature.
\end{abstract}

Keywords: Zika virus, Aedes aegypti, Venereal transmission

\section{Background}

Zika virus (ZIKV, Flavivirus, Flaviviridae) is an arbovirus that has undergone a rapid spread in the Pacific region and across tropical America since 2015, causing a severe pandemic in 2015-2016 [1-3]. Moreover, microcephaly and other congenital neurological malformations and disorders were associated with ZIKV infections worldwide, which have made this virus currently one of the most significant public health issues. ZIKV transmission to people is primarily through the bite of an infected Aedes mosquitoes, mainly Aedes aegypti [1, 4]. However, the description of other modes of transmission, like inter-human contamination, may also explain ZIKV emergence, its efficient spread and maintenance in nature [5-8]. Moreover, inter-mosquito transmission through the vertical route is also likely to play a role. Therefore, we experimentally demonstrated that ZIKV could be venereally transmitted between Ae. aegypti, a phenomenon that could help in perpetuating ZIKV in nature.

\footnotetext{
* Correspondence: lourenco@ioc.fiocruz.br

'Laboratório de Mosquitos Transmissores de Hematozoários, Instituto

Oswaldo Cruz, Fiocruz, Rio de Janeiro, Brazil

Full list of author information is available at the end of the article
}

\section{Methods}

We experimentally assessed venereal transmission in two populations of Brazilian Ae. aegypti mosquitoes: Urca (URC; F2 generation), Rio de Janeiro, coastal Southeast region, and Goiânia (GOI; F1 generation), Goiás, inland Central-West region. Their F0 generation tested negative for ZIKV by qRT-PCR as described previously [9]. Mosquitoes were reared at $26 \pm 1{ }^{\circ} \mathrm{C}$, $12 \mathrm{~h}: 12 \mathrm{~h}$ light:dark cycle and $70 \pm 10 \%$ humidity (standardized environmental condition, SEC) as previously described $[9,10]$. Mosquitoes were sexed at the pupal stage, and the emerged adults of each gender were maintained in distinct cages supplied with a $10 \%$ sucrose solution at SEC. Virgin Ae. aegypti females aged 5-7 days post-emergence were orally challenged with two ZIKV strains belonging to the Asian lineage, namely ZIKVRio-U1 (GenBank: KU926309) and ZIKV-PE243 (GenBank: KX197192), respectively, isolated from humans in Southeast [11] and Northeast [12] Brazil. These ZIKV strains display 99\% nucleotide and amino acid identity and may similarly infect Brazilian Ae. aegypti [9-12]. Accordingly, females were provided with a mixture containing two parts of washed rabbit erythrocytes and one part of viral suspension at a final titter of $10^{6} \mathrm{PFU} / \mathrm{ml}$ as described previously [9]. We incubated sets of fully 
engorged females at SEC in cylindrical carton cages (20 $\times 16 \mathrm{~cm}$ ) daily supplied with a $10 \%$ sucrose solution. Groups of 10-30 females corresponding to each combination of the mosquito population and virus strain were randomly killed, and body homogenates in culture medium were examined by RT-qPCR for determining infection rates (IR) on the 10th and 14th day postinfection (dpi) as described elsewhere [9]. At this same $\mathrm{dpi}$, virgin males of the same population, generation and age were introduced into the respective female-infected cages at two sex ratios (Table 1). Then, distinct groups of mosquitoes were allowed to freely mate for $30 \mathrm{~h}$ devoid of any food source, to avoid oral contamination, or for 5 days provided with a piece of cotton mesh imbibed with $10 \%$ sucrose solution on the top of the cage. In the last case, samples of the sucrose solution probed by mosquitoes were examined daily for the presence of ZIKV by RT-qPCR, and have always tested ZIKVnegative. On completion of the above-mentioned contact periods, samples of 30 females were dissected to determine insemination rates, that is, the proportion of females with spermatheca containing spermatozoids [13]. RNA was extracted from male entire body homogenates for determining IR by RT-qPCR and whole viral genome sequencing on the 14th day after mating as described $[9,11]$. Due to the scanty number of health or surviving males that mated with infected females, we decide to intrathoracically inject virgin males with ZIKV to access venereal transmission from male to female. Thus, the supernatant of the body homogenate of one venereally contaminated URC male was inoculated in other URC virgin males. After 10 and 14 days of incubation at SEC, URC virgin females were left to mate for $30 \mathrm{~h}$ (devoid of any food source) at a sex ratio of 1 male: 2 females, and incubated for 14 days at SEC. Male and female entire body homogenates were tested by RTqPCR [9]. Aiming to investigate possible genetic changes in the viral genome occurring during the venereal transmission, we also extracted RNA and sequenced the whole genome from the virus of the infectious meal taken by females as well as from a pool of five infected females that mated with the venereally contaminated males. Nucleotide sequences were aligned, edited and compared as described previously [11].

\section{Results}

Insemination rates were $50-90 \%$ and $100 \%$ in females kept in contact with males for $30 \mathrm{~h}$ and 5 days, respectively. IRs in orally challenged females ranged from $46 \%$ to 70\% in URC mosquitoes challenged with ZIKV-PE243 and ZIKV-Rio-U1, respectively (Table 1 ). Venereal transmission to males was achieved in mosquito groups whose females were infected with ZIKV-Rio-U1, where IRs in males was $0.9 \%$ in URC and $33 \%$ in GOI (median of viral loads in bodies of $1.5 \times 10^{6}$ RNA copies $/ \mathrm{ml}$; $\mathrm{CT} \leq 17.2$ ). No venereal transmission was detected in the mosquito groups infected with ZIKV-PE243, whose females coincidently had the lowest insemination rates. IRs of intrathoracically inoculated males were 87.5 and $97.9 \%$ at 10 and 14 days, respectively (Table 2). Viral load in bodies of males at 10 and 14 days after injection reached $3.6 \times 10^{6}$ and $9.8 \times 10^{6} \mathrm{RNA}$ copies/ml (median: $3.3 \times 10^{6}$ and $3.6 \times 10^{6}$; CT $\leq 15.6$ ), respectively. Males with 10 days after inoculation could not venereally transmit the virus. However, the venereal transmission was detected in $50 \%$ of females mated by males with 14 days after intrathoracic injection (viral load in bodies of positive females ranging from $3.4 \times 10^{2}$ to $9.8 \times 10^{2}$ RNA copies/ml; CT $\leq 28.8)$. The compared ZIKV genomes were identical, with the virus recovered from a venereally contaminated male (URC-ZIKVRioU1) presenting a single nucleotide substitution at position 1115 (protein E) in which a thymine was replaced by a cytosine, without generating amino acid change.

\section{Discussion}

Male Aedes mosquitoes have been found naturally infected with ZIKV in Africa [14] and South America [4], providing evidence that inter-mosquito contamination occurs in nature and this phenomenon may play some role in virus maintenance and viral evolution [15]. Being non-hematophagous, male mosquitoes may acquire an

Table 1 Infection rates in Aedes aegypti females orally challenged with ZIKV and males contaminated by the venereal route

\begin{tabular}{|c|c|c|c|c|c|c|}
\hline \multirow{2}{*}{$\begin{array}{l}\text { Mosquito } \\
\text { population }\end{array}$} & \multirow{2}{*}{$\begin{array}{l}\text { ZIKV } \\
\text { strain }\end{array}$} & \multirow{2}{*}{$\begin{array}{l}\text { Sex ratio } \\
\text { female: male } \\
\text { (insemination } \\
\text { rate) }\end{array}$} & \multicolumn{2}{|c|}{ Female orally challenged } & \multicolumn{2}{|c|}{ Male venereal transmission } \\
\hline & & & $\bar{n}$ & $\operatorname{IR}(\%)$ & $\bar{n}$ & IR (\%) \\
\hline \multirow[t]{3}{*}{ Urca } & RioU1 & $256: 256(90 \%)^{b}$ & 30 & 63 & 110 & 0.9 \\
\hline & RioU1 & $37: 19(97 \%)^{c}$ & 10 & 70 & 20 & 0 \\
\hline & PE243 & $76: 76(50 \%)^{b}$ & 30 & 46 & 38 & 0 \\
\hline Goiânia & RioU1 & $90: 45(100 \%)^{c}$ & 10 & 50 & 6 & 33.0 \\
\hline
\end{tabular}

Abbreviations: $n$ number of tested mosquitoes, $I R$ infection rate referring to the proportion of mosquitoes with infected body among tested ones

ansemination rate is the proportion of females with spermathecal containing spermatozoids

${ }^{\mathrm{b}}$ Contact for $30 \mathrm{~h}$

Contact for 5 days 
Table 2 Infection rates in Aedes aegypti males inoculated intrathoracically with ZIKV-RioU1 and female contaminated by the venereal route. Mosquitoes were let to copulate for $30 \mathrm{~h}$ devoid of any food source at a sex ratio of: 1 male: 2 females (81:162)

\begin{tabular}{lllll}
\hline $\begin{array}{l}\text { Days after } \\
\text { intrathoracic } \\
\text { inoculation } \\
\text { of males }\end{array}$ & Male inoculated intrathoracically & & \multicolumn{2}{l}{ Female venereal transmission } \\
\cline { 2 - 5 } 10 & $\mathrm{n}$ & $\mathrm{IR}-\mathrm{mi}(\%)$ & 19 & 0 \\
\hline 10 & 10 & 87.5 & 10 & 50 \\
\hline
\end{tabular}

Abbreviations: $n$ number of tested mosquitoes, $I R$ Infection rate referring to the proportion of mosquitoes with infected body among tested ones by RT-qPCR

arbovirus infection through the vertical route. Nevertheless, the venereal transmission has also been experimentally demonstrated for several pairings insect-arbovirus [15-17], including other flaviviruses such as Japanese encephalitis, dengue and St Louis encephalitis viruses [18-20]. We demonstrated that ZIKV could be venereally transmitted between Ae. aegypti of two geographically-distant populations. Males obtained the infection from females and vice versa. Moreover, the genome of the virus transmitted by the venereal route was identical to those orally absolved as well as infecting females, suggesting that no expressive genetic changes occur in the viral genome during the venereal transmission. The efficiency of the venereal transmission route may be greater than expected. The variation in insemination and infection rates in orally-challenged females suggest that not all of them had sexual contact with males, especially in the groups brought into contact for only $30 \mathrm{~h}$. The higher rate of venereal transmission from infected females to males (33\%) was detected in the group of mosquitoes in which contact time was 5 days and insemination rate was of $100 \%$, that is, all females had sexual contact with males. Considering that one male could have inseminated more than one female in such a group [13], it is possible that not all males had sexual contact with infected females, reducing the chance of venereal transmission. These data altogether may explain the large variation in male IRs.

Several factors have been proposed to explain the silent endemic/enzootic maintenance of ZIKV in Africa and Asia as well as the recent fast spread of this virus in the West Hemisphere, but they remain poorly understood. Although the main mode of maintenance of ZIKV in nature is supposed to be the primate-mosquitoprimate transmission cycle, evidence of inter-vertebrate (congenital, perinatal, sexual, occupational and others) $[1,5-7]$ and inter-invertebrate contamination routes (vertical and venereal) [8] may help in explaining the high capacity of ZIKV to be transmitted and spread.

\section{Conclusion}

We conclude that together with other modes of transmission, the venereal route in Aedes mosquitoes might contribute to ZIKV virus maintenance in nature.

\section{Acknowledgments}

The authors thank lule de Souza Bonelly, Keli Antunes Barbosa da Silva, Lidiane M. S. Raphael, Bruno Felix Pimentel Vianna and Maria Ignêz Bersot for technical support. To Luciano Moreira and Marli T. Cordeiro for providing virus isolated from Northeast Brazil.

\section{Funding}

This work was supported by the European Union's Horizon 2020 research and innovation programme (ZIKAlliance grant 734,548), CAPES-COFECUB Coordenação de Aperfeiçoamento de Pessoal de Nível Superior (grant 799/ 14), Fundação Carlos Chagas Filho de Amparo à Pesquisa do Estado do Rio de Janeiro (grants E-26/102.351/2013 and E-26/201.335/2016), Conselho Nacional Desenvolvimento Científico e Tecnológico (grant 309,577/2013-6) and National Institut of Health (grant 1 UO1 Al115595-01). The funders had no role in study design, data collection and analysis, decision to publish, or preparation of the manuscript.

\section{Availability of data and materials}

The data used in the present study are available from the corresponding author upon reasonable request.

\section{Authors' contributions}

SSC and RSF carried out mosquito rearing and experimental infections. SSC and ELT performed mosquito intrathoracic inoculation. SSC, RSF, RMM, MGC and AFB tested mosquito samples by molecular methods. AACS and MCB produced the viral stocks and sequenced and analyzed the whole virus genomes. MCB and ABF participated in producing reagents for mosquito experiments and helped to prepare the text. RLO and SSC conceived the study and analyzed data. RLO wrote the manuscript. All authors read and approved the final manuscript.

\section{Ethics approval}

This study was approved by the Institutional Ethics Committee on Animal Use (CEUA-IOC license LW-34/14) at the Instituto Oswaldo Cruz.

\section{Consent for publication}

Not applicable.

\section{Competing interests}

The authors declare that they have no competing interests.

\section{Publisher's Note}

Springer Nature remains neutral with regard to jurisdictional claims in published maps and institutional affiliations.

\section{Author details}

'Laboratório de Mosquitos Transmissores de Hematozoários, Instituto Oswaldo Cruz, Fiocruz, Rio de Janeiro, Brazil. Laboratório de Biologia Molecular de Flavivírus, Instituto Oswaldo Cruz, Fiocruz, Rio de Janeiro, Brazil. ${ }^{3}$ Laboratório de Biologia Molecular de Parasitos e Vetores, Instituto Oswaldo Cruz, Fiocruz, Rio de Janeiro, Brazil. ${ }^{4}$ Arboviruses and Insect Vectors, Institut Pasteur, Paris, France. 
Received: 5 September 2017 Accepted: 20 November 2017

Published online: 15 December 2017

\section{References}

1. Weaver SC, Costa MF, Garcia-Blanco A, Ko Al, Ribeiro GS, Saade G, et al. Zika virus: history, emergence, biology, and prospects for control. Antivir Res. 2016;130:69-80

2. Samy AM, Thomas SM, Wahed AA, Cohoon KP, Peterson AT. Mapping the global geographical potential of Zika vírus spread. Mem Inst Oswaldo Cruz. 2016;111(9):559-60.

3. Possas C, Brasil P, Marzochi MCA, Tanuri A, Martins R, Marques ETA, et al. Zika puzzle in Brazil: peculiar conditions of viral introduction and dissemination - a review. Mem Inst Oswaldo Cruz. 2017;112(5):319-27.

4. Ferreira-de-Brito A, Ribeiro IP, Miranda RM, Fernandes RS, Campos SS, Silva $K A B$, et al. First detection of natural infection of Aedes aegypti with Zika virus in Brazil and throughout South America. Mem Inst Oswaldo Cruz. 2016; 111(10):655-8.

5. Barzon L, Pacenti M, Franchin E, Lavezzo E, Trevisan M, Sgarabotto D, et al. Infection dynamics in a traveller with persistent shedding of Zika virus RNA in semen for six months after returning from Haiti to Italy, January 2016. Euro Surveill. 2016;21(32):30316.

6. Septfons A, Leparc-Goffart I, Couturier E, Franke F, Deniau J, Balestier A, et al. Travel-associated and autochthonous Zika virus infection in mainland France, 1 January to 15 July 2016. Euro Surveill. 2016;21(32):30315.

7. Aliota MT, Bassit L, Bradrick SS, Cox B, Garcia-Blanco MA, Gavegnano C, et al. Zika in the Americas, year 2: What have we learned? What gaps remain? A report from the Global Virus Network. Antivir Res. 2017;144:223-46.

8. Ciota AT, Bialosuknia SM, Ehrbar DJ, Kramer LD. Vertical transmission of Zika virus by Aedes aegypti and Ae. albopictus mosquitoes. Emerg Infect Dis. 2017;23(5):880-2

9. Fernandes RS, Campos SS, Ferreira-de-Brito A, Miranda MR, Silva KAB, Gonçalves MC, et al. Culex quinquefasciatus from Rio de Janeiro is not competent to transmit the local Zika virus. PLoS Negl Trop Dis. 2016;10(9): e0004993.

10. Campos SS. Estudo da transmissão vertical e venérea do vírus Zika em mosquitos Aedes aegypti. Rio de Janeiro, Brazil: MSc Thesis. Instituto Oswaldo Cruz: 2017

11. Bonaldo MC, Ribeiro IP, Lima NS, Santos AAC, Menezes LSR, Cruz SOD, et al. Isolation of infective Zika virus from urine and saliva of patients in Brazil. PLoS Negl Trop Dis. 2016;10(6):e0004816.

12. Donald CL, Brennan B, Cumberworth SL, Rezelj V, Clark JJ, Cordeiro MT, et al. Full genome sequence and sfRNA interferon antagonist activity of Zika virus from Recife, Brazil. PLoS Negl Trop Dis. 2016;10(10):e0005048.

13. Consoli RAGB, Lourenço-de-Oliveira R. Principais mosquitos de importância sanitária no Brasil. Rio de Janeiro: Editora Fiocruz; 1998.

14. Diallo D, Sall AA, Diagne CT, Faye O, Faye O, Ba Y, et al. Zika virus emergence in mosquitoes in southeastern Senegal, 2011. PLoS One. 2014; 9(10):e109442.

15. Higgs SB, BJ. Natural cycles of vector-borne pathogens. In: Marquardt WC, editor. Biology of disease vectors. Burlington: Elsevier Academic Press; 2004.

16. Mavale MS, Fulmali PV, Geevarghese G, Arankalle VA, Ghodke YS, Kanojia P, et al. Venereal transmission of Chandipura virus by Phlebotomus papatasi (Scopoli). Am J Trop Med Hyg. 2006;75(6):1151-2.

17. Mavale M, Parashar D, Sudeep A, Gokhale M, Geevarghese YG, Akhilesh V. Venereal transmission of chikungunya virus by Aedes aegypti mosquitoes (Diptera: Culicidae). Am J Trop Med Hyg. 2010;83(6):1242-4

18. Shroyer DA. Venereal transmission of St. Louis encephalitis virus by Culex quinquefasciatus males (Diptera: Culicidae). J Med Entomol. 1990;27(3):334-7.

19. Mourya DT, Soman RS. Venereal transmission of Japanese encephalitis virus in Culex bitaeniorhynchus. Indian J Med Res. 1999;109:202-3.

20. Rosen L. Sexual transmission of dengue viruses by Aedes albopictus. Am J Trop Med Hyg. 1987;37:398-402.

\section{Submit your next manuscript to BioMed Central and we will help you at every step:}

- We accept pre-submission inquiries

- Our selector tool helps you to find the most relevant journal

- We provide round the clock customer support

- Convenient online submission

- Thorough peer review

- Inclusion in PubMed and all major indexing services

- Maximum visibility for your research

Submit your manuscript at www.biomedcentral.com/submit
Biomed Central 